\title{
Quantification of vertical transmission of Neospora caninum in dairy cows in Minas Gerais, Brazil
}

\author{
Quantificação da transmissão vertical de Neospora caninum em vacas leiteiras de Minas Gerais, Brasil \\ Raquel Ribeiro Dias Santos ${ }^{1}$; Christiane Maria Barcellos Magalhães da Rocha' ${ }^{1}$; Tarcísio de Morais Gonçalves²; \\ Antônio Marcos Guimarães ${ }^{1 *}$ \\ ${ }^{1}$ Departamento de Medicina Veterinária, Universidade Federal de Lavras - UFLA, Lavras, MG, Brasil \\ ${ }^{2}$ Departamento de Zootecnia, Universidade Federal de Lavras - UFLA, Lavras, MG, Brasil
}

Received August 24, 2011

Accepted April 12, 2012

\begin{abstract}
The objective of this cross-sectional study was to estimate the rate of vertical transmission and to investigate horizontal transmission of Neospora caninum and occurrences of reproductive abnormalities in seropositive dairy cows on two farms in the state of Minas Gerais, Brazil. The frequency of cows seropositive for $N$. caninum according to the indirect fluorescent antibody test (IFAT) was 39.4\% (93/236) for Farm A and 31.4\% (32/102) for the Farm B ( $\mathrm{p}>0.05$ ). The mean vertical transmission rates for $N$. caninum were $29 \%$ and $9 \%$ for the herds of Farms A and B, respectively. No negative effects $(\mathrm{p}>0.05)$ from infection by $N$. caninum were observed regarding milk production and occurrences of reproductive abnormalities in herds A and B.
\end{abstract}

Keywords: Neosporosis, horizontal infection, reproductive abnormalities, IFAT.

\section{Resumo}

O objetivo deste estudo transversal foi estimar a taxa de transmissão vertical e investigar a transmissão horizontal de Neospora caninum, e a ocorrência de alterações reprodutivas em vacas leiteiras soropositivas em duas fazendas no Estado de Minas Gerais, Brasil. A frequência de vacas soropositivas a $N$. caninum pelo teste de imunofluorescência indireta (RIFI) foi de 39,4\% (93/236) e 31,4\% (32/102) para as fazendas A e B, respectivamente. A taxa média de transmissão vertical de $N$. caninum, respectivamente, foi de $29 \%$ e $9 \%$ para os rebanhos A e B. Não foi observado nenhum efeito negativo $(\mathrm{p}>0,05)$ da infecção por $N$. caninum sobre a produção de leite e a ocorrência de alteraçóes reprodutivas nos rebanhos A e B.

Palavras-chave: Neosporose, infecção horizontal, alterações reprodutivas, RIFI.

Neospora caninum (Apicomplexa: Sarcocystidae) is an intracellular obligate parasite that has gained prominence as an important pathogen since its discovery. It affects several animal species, especially dairy cows, among which it is considered to be one of the main causes of abortions and stillbirths around the world (DUBEY, 2003). It is one of the most efficient parasites transmitted transplacentally, among all the microorganisms that affect cattle (DUBEY et al., 2007).

Infection by $N$. caninum is widely distributed among the dairy cows in the state of Minas Gerais, Brazil (MELO et al., 2001; GUEDES et al., 2008). However, there is a shortage of information on the estimated vertical transmission rates for $N$. caninum and occurrences of horizontal transmission; and on the impact of

\footnotetext{
*Corresponding author: Antônio Marcos Guimarães

Laboratório de Doenças Parasitárias, Departamento de Medicina Veterinária, Universidade Federal de Lavras - UFLA, CP 3037, CEP 37200-000, Lavras, MG, Brasil

e-mail:amg@dmv.ufla.br
}

this parasite on the production of dairy cattle and as the cause of reproductive problems, in this state and in the country. These knowledge gaps were the motivation for conducting the present study, which aimed to fill these gaps.

This cross-sectional study was carried out on two farms producing type B milk in the state of Minas Gerais. Farm A was located in the municipality of Bom Sucesso, with an area of 408 ha and a herd of 260 cows. Of these, 85 were of FriesianHolstein breed and were in lactation with a mean production of $20.5 \mathrm{~L} /$ day by means of mechanical milking twice a day. The production was semi-intensive and the animals were fed with corn silage, feed and pasture. The cows had constant veterinarian assistance and, in addition to the mandatory vaccinations, they were vaccinated against infectious bovine rhinotracheitis (IBR), leptospirosis, rabies and clostridiosis annually. The three dogs of the farm had access to the cattle and also to these animals' water and food. Presence of wild canids had also been reported. Although the placental remains, dead fetuses, abortions and dead animals 
were usually buried, it was common for the dogs to have access to these materials. The farm had a record of the parturition interval, occurrences of abortions, reproductive abnormalities, vaccinations, dairy production and genealogical tree for three generations.

Farm B was located in the municipality of São João Del Rei, with an area of 280 ha, and had a total of 117 cows, of which 50 were crossbred (Friesian-Holstein $\times$ Zebu) in lactation, with a mean production of $22 \mathrm{~L} /$ day. The nutritional, reproductive and sanitary management characteristics were similar to those reported for Farm A. On Farm B, between three and eight dogs were present, all of unknown origin (stray dogs), and, since there was no procedure for disposing of placental remains, stillbirths, abortion remains and dead animals, these dogs would usually have access to these materials. No wild canids were reported to be present. Farm B kept the same types of records as mentioned above for Farm A.

From Farms A and B, totals of 236 and 102 cow blood samples respectively $(3 \mathrm{~mL})$ were drawn by means of puncturing the coccygeal vein, in $10 \mathrm{~mL}$ tubes, without anticoagulant, between March and June 2007. The blood collection was carried out once on each cow in lactation and on female calves above the age of four months. After centrifuging the blood samples, the serum was kept frozen at $-20{ }^{\circ} \mathrm{C}$, until the time of performing the serological tests. The reaction of the indirect immunofluorescence antibody test (IFAT) was carried out in accordance with the technique described by Paré et al. (1995). The source of antigens, glass slides bearing tachyzoites from $N$. caninum (Imunodot Laboratory, Jaboticabal, SP, Brazil) and conjugated bovine anti-IgG (Sigma, St. Louis, MO, USA). The reactions were considered to be positive at the dilution of 1:200 (DUBEY; SCHARES, 2006).

The frequency of vertical transmission was estimated by means of diagrams on herds A and B (genealogical trees), in accordance with the methodology described by Bergeron et al. (2000). Relationships were described as families when there was information on the serological status for $N$. caninum regarding the mother and daughter, respectively. For Farm A, 68 families and 86 mother-daughter pairs were used. For Farm B, 30 families and 32 mother-daughter pairs were used. The vertical transmission rate was estimated based on the proportion of seropositive daughters born from seropositive mothers. When the cow had more than one calf (mother-daughter pair), only one pair was considered, which was chosen randomly. Horizontal transmission was also estimated also from diagrams on herds $\mathrm{A}$ and $\mathrm{B}$. However, to calculate the horizontal transmission, only the seropositive cows or calves born from a seronegative mother that had at least two sisters that were also seronegative were included (BERGERON et al.,
2000; SCHARES et al., 1998). When a cow had more than one calf, the same criteria explained above were used.

During the visit to each farm, a questionnaire on the main animal health characteristics of herds A and B was filled out. Two databases were created using the Excel software for statistical analysis on the production variables (milk production corrected to 305 days and the number of days in lactation) and reproductive variables (Table 1), and on the serological test results (IFAT): 1) production data on 39 cows and 2) reproductive data on 103 cows.

The production and reproductive data from farms A and B were analyzed together. On both farms, only animals above the age of 23 months and cows with periodic weighing of their milk were included in the statistical analysis. The descriptive analyses on all the variables of this study were carried out using the SAS software (1999). Since abortion is the most frequent clinical sign among adult cows infected by $N$. caninum, the animals were categorized as those with and those without a history of abortion. Then, the association between seropositivity of the cow to $N$. caninum and reproductive problems was determined through the chi-square test. To assess the effect of $N$. caninum on milk production, the weight of each cow's milk was used to delineate the lactation curve and estimate the milk production for 305 days. After estimating the lactation, variance analysis was carried out.

The frequencies of cows seropositive for $N$. caninum were $39.4 \%$ (93/236) and 31.4\% (32/102), for farms A and B, respectively. The mean overall frequency for the two herds was $37.0 \%$ (125/338). The vertical transmission was, respectively, $29.0 \%$ and $9.0 \%$ for herd $A(25 / 86)$ and herd $B(3 / 32)$. The mean overall frequency of congenital infection in the two herds was $23.7 \%(28 / 118)$. The horizontal transmission was $2.3 \%$ on farm A (2/86) and $3.1 \%$ on farm B (1/32). The mean overall frequency of horizontal transmission in the two herds was $2.5 \%(3 / 118)$.

The frequency of vertical transmission on farms $A$ and $B$ was lower than what was reported in Argentina (37.1\%) (MORÉ et al., 2009), and this can be partly explained by the size of the sample and the methodology used. To estimate the vertical transmission, the proportion of positive female calves born from mothers that were positive for $N$. caninum was calculated. Thus, the serological status of the animals on the day of the blood sampling was what was used to estimate the vertical transmission rate (BERGERON et al., 2000). This methodology may contain small flaws. For example, a mother that at the time of the blood sampling was considered positive may have been negative at the time of giving birth and may have produced a negative daughter. Nonetheless, the mother could have acquired the infection after giving birth through horizontal transmission. These flaws can overestimate the vertical

Table 1. Frequency of abortions and reproductive abnormalities according to the serological status for Neospora caninum, through the reaction of the indirect immunofluorescence test (IFAT; 1:200), in two dairy herds in the state of Minas Gerais, Brazil.

\begin{tabular}{|c|c|c|c|c|}
\hline Variable & $\begin{array}{l}N+ \\
(\%)\end{array}$ & $\begin{array}{l}N_{-} \\
(\%)\end{array}$ & Total & $\begin{array}{c}p \\
\text { value }\end{array}$ \\
\hline Abortion & $1(2.9)$ & $7(10.1)$ & $8(7.8)$ & 0.199 \\
\hline Reproductive abnormalities* & $7(20.6)$ & $13(18.8)$ & $20(19.4)$ & 0.398 \\
\hline Normal (without reproductive abnormalities) & $26(76.5)$ & $49(71.0)$ & $75(72.8)$ & \\
\hline Total & $34(100)$ & $69(100)$ & $103(100)$ & \\
\hline
\end{tabular}

*Placenta retention (13), stillbirth (3), embryo death (2), uterine prolapse (1), ovarian cyst (1). 
transmission rate and underestimate the horizontal transmission (BERGERON et al., 2000). Another factor that could explain the low frequency of vertical transmission is that cows that are seropositive for $N$. caninum are usually eliminated from the herd at an earlier stage, because they present low reproductive rates (BERGERON et al., 2000). In this study, the low occurrence of horizontal transmission on farms $\mathrm{A}$ and $\mathrm{B}$ was probably related to using a more restrictive criteria to estimate this, adapted from the study by Schares et al. (1998), such that it remained well below the $47 \%$ observed among dairy cattle in Argentina (MORÉ et al., 2009).

In the present study, the serological status for $N$. caninum did not have any significant effect on milk production, and this results was similar to what was observed by López-Gatius et al. (2005), among dairy cattle in Spain. However, this does not agree with the findings of Romero et al. (2005), in Costa Rica, who observed a significant reduction in milk production from seropositive cows. In herds $\mathrm{A}$ and $\mathrm{B}$, there was no significant association between seropositivity and persistency of lactation, which is similar to what was reported by López-Gatius et al. (2005), in dairy herds consisting of high-production cows.

As shown in Table 1, herds A and B were analyzed together, because of the low number of animals with histories of abortion and reproductive abnormalities. There was no significant association $(\mathrm{p}<0.05)$ between occurrences of abortion and seropositivity for $N$. caninum, and this result was similar to what was observed in relation to the other reproductive abnormalities analyzed. Romero et al. (2005) did not observe any effect ( $p>0.05)$ from the seropositivity with regard to occurrences of abortions and reproduction abnormalities among dairy cattle in Costa Rica. Nevertheless, in Spain, seropositive dairy cows presented five times greater chance of aborting than shown by seronegative cows (GONZÁLEZ-WARLETA et al., 2008). No decrease in fertility rates has yet been demonstrated among female cattle infected by $N$. caninum, and abortion has been described as the only clinical sign among adult animals (LÓPEZ-GATIUS et al., 2005).

Infection by $N$. caninum is widely distributed among dairy cattle in several regions in Brazil (DUBEY; SCHARES, 2011). However, there are no studies on the pathogenic characteristics of the $N$. caninum isolates that infect these cattle. This is important information, considering that a foreign study has indicated the possibility that of a strain of $N$. caninum with low virulence and reduced rate of congenital transmission may circulate among cattle. This was shown in a murine model, using isolates from an asymptomatic calf that was naturally infected (ROJO-MONTEJO et al., 2009). Thus, it is also possible that the herds from farms $\mathrm{A}$ and $\mathrm{B}$ were infected with a low virulence strain of N. caninum (SCHARES et al., 2001). This would partly explain the results obtained previously from dairy cattle in the southern region of the state of Minas Gerais, where infection by $N$. caninum presents high prevalence, but there is no significant association with occurrences of abortion, and the frequency of congenital transmission is relatively low (GUEDES et al., 2008).

Based on the serological evidence, the results from the present study indicate that congenital infection predominates in $N$. caninum transmission and that the serological status does not have a negative effect on the production and reproductive parameters of the dairy herds in question.

\section{Acknowledgements}

To the Research Support Foundation of the State of Minas Gerais (Fundação de Apoio à Pesquisa do Estado de Minas Gerais, FAPEMIG - No CVZ APQ-7963-5.04/07) for financial support.

\section{References}

Bergeron N, Fecteau G, Paré J, Martineau R, Villeneuve A. Vertical and horizontal transmission of Neospora caninum in dairy herds in Québec. Can Vet J 2000; 41(6): 464-467. PMid:10857030 PMCid:1476225.

Dubey JP, Schares G, Ortega-Mora LM. Epidemiology and control of neosporosis and Neospora caninum. Clin Microbiol Rev 2007; 20(2): 323-367. PMid:17428888 PMCid:1865591. http:// dx.doi.org/10.1128/CMR.00031-06

Dubey JP, Schares G. Diagnosis of bovine neosporosis. Vet Parasitol 2006; 140(1-2): 1-34. PMid:16730126. http://dx.doi. org/10.1016/j.vetpar.2006.03.035

Dubey JP, Schares G. Neosporosis in animals - The last five years. Vet Parasitol 2011; 180(1-2): 90-108. PMid:21704458. http://dx.doi. org/10.1016/j.vetpar.2011.05.031

Dubey JP. Review of Neospora caninum and neosporosis in animals. Korean J Parasitol 2003; 41(1):1-16. PMid:12666725 PMCid:2717477. http://dx.doi.org/10.3347/kjp.2003.41.1.1

González-Warleta M, Castro-Hermida JA, Carro-Corral C, Cortizo-Mella J, Mezo M. Epidemiology of neosporosis in dairy cattle in Galícia (NW Spain). Parasitol Res 2008; 102(2): 243-249. PMid:17899194.

Guedes MHP, Guimarães AM, Rocha CMBM, Hirsch C. Frequência de anticorpos anti-Neospora caninum em vacas e fetos provenientes de municípios do Sul de Minas Gerais. Rev Bras Parasitol Vet 2008; 17(4): 189-194. PMid:19265576.

López-Gatius F, Santolaria P, Almería S. Neospora caninum infection does not affect the fertility of dairy cows in herds with high incidence of Neospora-associated abortions. J Vet Med B 2005; 52(1): 51-53. PMid:15703002. http://dx.doi.org/10.1111/j.1439-0450.2004.00811.x

Melo CB, Leite RC, Souza GN, Leite RC. Frequência de infecção por Neospora caninum em dois diferentes sistemas de produção de leite e fatores predisponentes à infecçáo em bovinos em Minas Gerais. Rev Bras Parasitol Vet 2001; 10(2): 67-74.

Moré G, Bacigalupe D, Basso W, Rambeaud M, Beltrame F, Ramirez B, et al. Frequency of horizontal and vertical transmission for Sarcocystis cruzi and Neospora caninum in dairy cattle. Vet Parasitol 2009; 160(1-2): 51-54. PMid:19070964. http://dx.doi.org/10.1016/j.vetpar.2008.10.081

Paré J, Hietala SK, Thurmond MC. Interpretation of an indirect fluorescent antibody test for diagnosis of Neospora sp. infection in cattle. J Vet Diagn Invest 1995; 7(2): 273-275. PMid:7619917. http://dx.doi. org/10.1177/104063879500700222

Rojo-Montejo S, Collantes-Fernández E, Regidor-Cerrillo J, ÁlvarezGarcía G, Marugan-Hernández V, Pedraza-Díaz S, et al. Isolation and characterization of a bovine isolate of Neospora caninum with low virulence. Vet Parasitol 2009; 159(1): 7-16. PMid:19027235. http:// dx.doi.org/10.1016/j.vetpar.2008.10.009

Romero JJ, Breda SV, Varga B, Dolz G, Frankena K. Effect of neosporosis on productive and reproductive performance of dairy cattle in Costa 
Rica. Theriogenology 2005; 64(9): 1928-1939. PMid:15936812. http:// dx.doi.org/10.1016/j.theriogenology.2005.03.023

SAS Institute. User's guide: estatistics. Cary; 1999.

Schares G, Heydorn AO, Cüppers A, Conraths FJ, Mehlhorn H. Hammondia heydorni-like oocysts shed by a naturally infected dog and Neospora caninum NC-1 cannot be distinguished. Parasitol
Res 2001; 87(10): 808-816. PMid:11688886. http://dx.doi.org/10.1007/ s004360100445

Schares G, Peters M, Wurm R, Bärwald A, Conraths FJ. The efficiency of vertical transmission of Neospora caninum in dairy cattle analysed by serological techniques. Vet Parasitol 1998; 80(2): 87-98. http://dx.doi. org/10.1016/S0304-4017(98)00195-2 